\title{
Geoarchaeological investigations at Sormás-Török-földek, a Neolithic site in Southwestern Transdanubia, Hungary
}

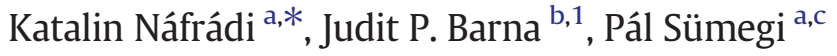 \\ a Department of Geology and Palaeontology, University of Szeged, H-6722 Szeged, Egyetem utca 2-6, Hungary \\ b Balatoni Museum, H-8360 Keszthely, Múzeum utca 2, Hungary \\ c Archaeological Institute of the Hungarian Academy of Sciences, H-1014 Budapest, Úri utca 49, Hungary
}

\section{A R T I C L E I N F O}

\section{Article history:}

Received 20 August 2014

Accepted 18 September 2014

Available online 11 October 2014

\section{Keywords:}

Palaeoecology

Charcoal analysis

Pollen analysis

Archaeobotany

Neolithic circular ditch-systems (= NCDS)

Late Neolithic settlement

Southwestern Hungary

\begin{abstract}
A B S T R A C T
A comprehensive and detailed picture was gained about the historical events and the natural environment of Southwestern Hungary at the beginning of the 5th millennium BC. The archaeological site at Sormás-Törökföldek provided a favoured unique opportunity to study the formation process of the Middle Neolithic Sopot and Late Neolithic Lengyel culture. Wood charcoal analysis provided site-related information about the natural milieu of the site. Anthracological analysis has not been carried out in Southwestern Hungary so far, whereby more than 3600 fragments of charred wood remains were identified. Our dataset was compared to pollen analytical, archaeobotanical and archaeological data to create a more accurate vegetation picture for this period of time and to reconstruct the utilization of wood during Middle and Late Neolithic.

Charcoal assemblage reflects the composition of the woodland around the site. Based on the results a thermophilous Quercus forest mixed with Fagus, Fraxinus, Acer, Alnus and Ulmus existed in the study site during the Middle and Late Neolithic and different types of wood were used for fire wood and for construction purposes as well. Anthracological analysis of samples from Sormás-Török-földek enabled a more accurate vegetation reconstruction for the study site by the comparison to previously known pollen analytical data and added extra information regarding the local vegetation and wood utilization for the Middle and Late Neolithic.
\end{abstract}

(c) 2014 Elsevier Ltd. All rights reserved.

\section{Introduction}

During the M7 motorway excavations between 1999 and 2007 many important prehistoric settlements were revealed in Zala County, Southwestern Hungary (Transdanubia). This territory played an intermediating role between the Balkans and Central and Eastern Europe during Neolithization. Cultural waves from the Balkans passed through Southwestern Transdanubia in three successive waves beginning from the appearance of the Starčevo culture in the Early Neolithic. The emergence of the LBK was the result of the second wave arriving from the south in the Middle Neolithic, inspiring the spread of the LBK into Central Europe. The formation of the Lengyel culture can be connected with the third cultural wave of southern origin. Furthermore, the development of the Middle Chalcolithic Balaton-Lasinja culture can also be correlated with similarly strong cultural impacts from the south (Bánffy, 1995, 2004, 2013). One of the settlements, Sormás-Török-földek, represents the material remains of the Starčevo, Linear Band Pottery Culture

\footnotetext{
* Corresponding author at: Department of Geology and Palaeontology, University of Szeged, H-6722 Szeged, Egyetem utca 2-6, Hungary Tel./fax: + 3662544893.

E-mail addresses: nafradi@geo.u-szeged.hu (K. Náfrádi),judit.pbarna@balatonimuzeum.hu (J.P. Barna), sumegi@geo.u-szeged.hu (P. Sümegi).

1 Tel.: + 3683312351 .
}

(LBK) and both the Sopot and Lengyel cultures dated to the Early, Middle and Late Neolithic of the Carpathian Basin. The find assemblage on the site at Sormás-Török-földek dated to the turn of the Middle and Late Neolithic provided an opportunity to redraw the picture about the Transdanubian Sopot culture formed earlier on the basis of sporadic data.

As it was generally viewed, the two main components in the formation of the culture were the Central European (Transdanubian) Linear Band Pottery culture (LBK) and the Sopot culture. It has also been accepted that there was genetic continuity between the LBK and the Lengyel cultures, in the first instance on the grounds of the high scale coincidence of the territories of both cultures; even though no factual pieces of evidence of the continuity have been available. Transdanubia, South-Western Slovakia and the western part of Burgenland comprise the territory of the emergence of the Lengyel culture (Kalicz, 2001, 2007; Čižmař et al., 2008), where, during the period prior to the emergence of the Lengyel culture, different territorial groups of the LBK had settled: the Keszthely, the Music Note, the Zselíz groups and the Šarka style. The presence of the Transdanubian Sopot culture - on the grounds of the settlement pattern earlier thought to be loose and dispersed - seemed to be hardly at all correlated with that of the LBK, but at the same time the high scale similarity found in the material culture proved that there was direct correlation between the Sopot and the Lengyel cultures. Accordingly, the genesis of the 
Lengyel culture was considered as a process taking place on the multicultural substrate of the LBK groups in which the Sopot culture played a catalyser role fostering transformations.

Thanks to the intensive research activities related to the M7 motorway excavations it became clear that the Transdanubian Sopot culture had played a much more determinative role in the formation process of the Lengyel culture as it was supposed earlier (Kalicz et al., 2007; P. Barna, 2007a; Kalicz et al., 2012). Therefore the re-evaluation of the Sopot culture as one of the basic components of the Lengyel culture (Kalicz, 1988) made it also necessary to revise the earlier opinions and statements made about the formation of the Lengyel culture. This was even more motivated by the fact that on the site at Sormás-Törökföldek, besides the find material from the Sopot culture, the find material from the formative phase of the Lengyel culture was also found. The comparison of the altogether three ditch-systems excavated on the two Sormás sites made possible to approach the period at the turn of the Middle and Late Neolithic also from a new aspect.

The archaeological findings obtained from the site consist of not only classical archaeological material such as pottery, stone, bone and antler artefacts but anthropological, archaeozoological, anthracological and archaeobotanical materials as well that are very important from a geoarchaeological point of view.

Wood charcoal analysis is an applied method in Quaternary research that provides information about vegetation changes. It helps to reconstruct the vegetation cover for a certain time period via the analysis of the anatomical character of charred woody tissues and cells (Greguss, 1945, 1972). Its significance lies in the fact that it makes the reconstruction of the former local flora possible adding extra information to complex palaeoecological reconstructions. Archaeoanthracology (Vernet, 2002) focuses on the wood used by the different cultures and populations (Jansen and Nelle, 2012). It enables us to study the anthropogenic impact on vegetation and plant communities and the usage of wood material (Neumann, 1992; Kreuz, 1992). The presence of humans supposes the transformation of the vegetation in the surroundings of the settlements. Gathering, plant cultivation, animal husbandry, the need of firewood and the increasing population all contribute to trigger deforestation. So vegetation development is highly influenced by human activities in the vicinity of former settlements.

Anthracological analyses have not been carried out in this area before. Due to the development of Quaternary research during the last decades in Hungary (Sümegi, 1989, 1997, 1998, 2001, 2003) anthracological studies became significant in palaeoenvironmental studies (Rudner, 1994, 2001, 2002; Sümegi and Rudner, 2001). However, it is still a less known area amongst archaeologists and palaeoecologists in Hungary. Furthermore, anthracological analysis is lacking in most palaeoecological studies.

Our aim was to outline the palaeoecological background of the Middle-Late Neolithic site in Southwestern Hungary during different habitation phases of Neolithic populations. We attempted to complete the results of the previous pollen analyses (Juhász, 2004, 2007) and to reconstruct the former local vegetation by the examination of wood macro remains and the results of palynological data. Furthermore, to bring to light which wood taxa were used by Neolithic populations and to investigate their impact on the vegetation. At the same time, we would like to draw attention to the importance of the method and give extra data to previous palaeoecological studies in Southwestern Hungary. In other respect the combination of the different methods might strengthen or complete the results of previous analyses so we can achieve a more accurate vegetation picture for the site on a local and regional scale and have a sight into the usage of wood during Neolithic.

\section{Study area}

The site at Sormás-Török-földek is situated on the southern side of a north-south oriented natural elevation (Fig. 1), about $182 \mathrm{~m}$ above sealevel. The Mántai Stream borders this elevation in the east. Another Neolithic site named Sormás-Mántai-dủlő is situated on the other bank of the stream. Its height above sea-level is about $164.5 \mathrm{~m}$. Both Sormás sites are very close to each other not only in a physical, but also in a chronological and cultural sense (P. Barna, 2007a).

The climate of the study area is temperate cold and temperate humid. The south part of the region enjoys a Subatlantic, while that of the southwest a Subalpine climate. The mean annual temperature is $9-9.8{ }^{\circ} \mathrm{C}$. The mean annual precipitation on the southwestern and southern part is $800 \mathrm{~mm}$ (Marosi and Somogyi, 1990).

The vegetation cover is quite diverse as a consequence of the different climatic and soil characters. On the south and southeast part of the county sessile oak forest mixed with hornbeam trees (Querco petraeae-Carpinetum), beech grove (Vicio oroboidi-Fagetum), pubescent and Austrian oak forest (Quercetum pubescenti-cerris), dwarf willow forest (Salicetum triandrae), willow-poplar gallery forest (Salicetum albae-fragilis) and oak-ash-elm gallery forest (Querco-Ulmetum) exist (Marosi and Somogyi, 1990).

The typical soil types are as follows. On higher loess covered surfaces lessivage brown forest soil and chernozem brown forest soils have developed. On the edges of river valleys leached brown forest soil, along rivers and on alluvial deposits hydromorph soil prevails. On
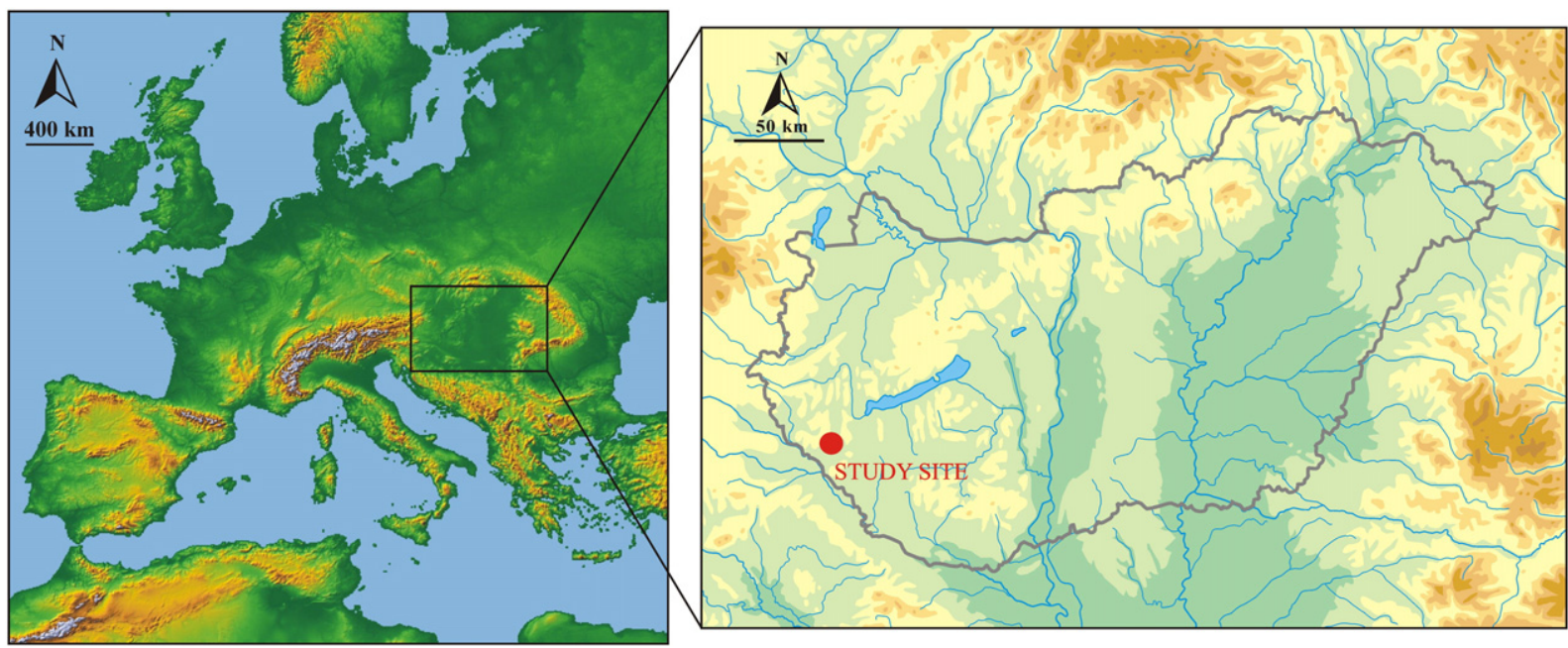

Fig. 1. Location of Sormás-Török-földek. 
periglacial sediments and on loess covered surfaces pseudogley brown forest soils developed (Marosi and Somogyi, 1990).

\section{Archaeological background}

\subsection{The Neolithic sequence of Western Hungary}

Due to the fact that cultural development was different in the western and eastern half of the Carpathian Basin prior to the Late Copper Age we focus on the Neolithic sequence of the western part of Hungary called Transdanubia (Biró, 2003).

The dawn of the Neolithic is associated with the appearance of the Starčevo culture of southern origin in the first half of the 6th millennium (Kalicz, 1990). It is debated to what extent the local Late Mesolithic population of Transdanubia took part in the formation process of the earliest food-producing culture of the region (Bánffy, 2004; Oross and Bánffy, 2009). A unique site of the culture with more than 400 features, dated to the final phase of the Starčevo culture, was discovered and excavated at Alsónyék-Bátaszék (Bánffy et al., 2010).

The Middle Neolithic period corresponds to the life of the LBK between roughly 5500 cal BC and 5000 cal BC (Oross and Bánffy, 2009). Several developmental phases could be distinguished in the LBK sequence of Transdanubia (Table 1 ).

The gradual formation of the LBK can be dated around $5500 \mathrm{cal}$ BC. According to an "integrationist theory", it took place on the ground of an essentially Mesolithic subsistence, complemented by Neolithic elements brought here by migrant late Starčevo groups (type site of the formative phase: Szentgyörgyvölgy-Pityerdomb) (Oross and Bánffy, 2009; Bánffy and Oross, 2010). The end of the LBK falls around $5000 / 4900 \mathrm{cal} B C$ and coincides in time with the emergence of the Lengyel culture.

During the Late Neolithic period of Transdanubia, people of the Keszthely group along with the Sopot culture, migrating from the south to Transdanubia, took part in the multicultural formation process of the Late Neolithic/Early Copper Age Lengyel culture (around the turn of the 6 th to the 5 th millennium). The absolute chronology of the formative phase of the Lengyel culture can be determined on the basis of radiocarbon dates obtained from the sites at Esztergályhorváti (49904710 cal BC (68,2\%)) and Sormás-Török-földek (4780-4690 cal BC (68,2\%)) (Stadler and Ruttkay, 2007; P. Barna, 2007a; P. Barna and Pásztor, 2011, Table 1.). The classical phase of the Lengyel culture (previously named as phase I) is characterised by the use of red paintings on the pottery. Radiocarbon dates are not available from this developmental phase to date.

The next developing phase of the Lengyel culture, characterised by the use of crusted white paintings on the pottery, can be dated only by conventional radiocarbon dates which seem to be too young. Therefore they are not comparable with the calibrated dates (see e.g. Zalavár-Mekenye). The last ("unpainted") phase of the Lengyel culture (phase III) falls already into the Early Cooper Age. It can be dated on the basis of radiocarbon dates obtained from a site at ZalaszentbalázsSzőlőhegyi mező between 4690-4450 cal BC (68.2\%); 4720-4360 cal BC (95,4\%) and 4450-4370 cal BC (68,2\%); 4690-4340 cal BC (95,4\%) (Oross, Marton, Whittle, Hedges and Cramp, 2010, Table 2).

\subsection{The Late Neolithic archaeological material of the site at Sormás- Török-földek}

The Sopot and early Lengyel potteries mostly share common forms and decorations. There are only a few differences between them. The high similarity of ceramics of the two cultures sometimes hampers correct assignment. The ratio of the given forms, decoration motifs and especially the different coloured painted pottery are determinative for the inner dating of the Sormás-Török-földek site. The high number of finds considered to be of ritual character found in Sormás-Török-földek, is a feature that could be observed also in other late Sopot sites in Southwestern Transdanubia (e.g. Sormás-Mántai-dűlő, Petrivente, Becsehelyi I., see Kalicz et al., 2007; P. Barna, 2007b). This feature compared to Sopot sites in Slavonia and in other territories of Croatia, must be attributed to the unique territorial and chronological characteristics of the Southwestern Transdanubian Sopot sites.

Foreign pottery of Korenovo, Butmir and Vinča style came to light in both Sormás sites. The most intense foreign influence can be recognised from the Butmir culture, which can be shown on various levels (P. Barna and Biró, 2009; P. Barna, 2009).

A large amount of stone materials was found on both Sormás sites. Examinations contributed greatly to the clarification of the communication systems of the two Sormás settlements. Compared to the excavation area's size the frequency of stone artefacts is low. Characteristic elements of the raw material spectrum are the grey flint and radiolarites. Apart from these types of raw materials, known from the Bakony and the Mecsek mountains, a raw material from an unidentified source is also significant, possibly pointing to southern connections. Long distance raw materials primarily occur amongst polished stone tools (greenschist, hornfels), but some long distance materials also occur amongst the typical regional raw materials for chipped flint tools, from outside of the Carpathian Basin: Lessini flint, Prut flint and Jurassic Krakow flint (P. Barna and Biró, 2009).

\subsection{Habitation phases}

On the basis of inner evidences four different habitation phases with further sub-phases can be distinguished in the site at Sormás-Törökföldek (subphases No. 1-4). The earliest habitation phase is composed by two little settlements represented by a few sporadic features of the Starčevo culture (1st habitation phase; 6000/5900-5500 cal BC). The

Table 1

Chronology of Early, Middle and Late Neolithic cultures and habitation phases of Sormás-Török-földek in Southwestern Transdanubia.

\begin{tabular}{|c|c|c|c|c|}
\hline \multirow[t]{2}{*}{ Age } & \multirow[t]{2}{*}{ Archaeological period } & \multicolumn{3}{|c|}{ Archaeological data from the site at Sormás-Török-földek } \\
\hline & & Habitation phase & Sub-phase & Absolute chronology \\
\hline $4900-4700$ cal BC & $\begin{array}{l}\text { Late Neolithic } \\
\text { (the formative phase of the Lengyel culture) }\end{array}$ & 4th habitation phase & $4 b$ & $\begin{array}{l}\text { VERA-3538: } 4780-4690 \text { cal BC }(68,2 \%) \text {; } \\
4830-4610 \text { cal BC }(95,4 \%)\end{array}$ \\
\hline 5000-4500 cal BC (Kalicz, 2007) & $\begin{array}{l}\text { Middle and Late Neolithic transition } \\
\text { (Sopot culture) }\end{array}$ & 3rd habitation phase & $3 b$ & $\begin{array}{l}\text { VERA-3539: } 4790-4700 \text { cal BC }(68,2 \%) \\
4840-4610 \text { cal BC }(95,4 \%) \text {; } \\
\text { VERA 3098: } 4910-4790 \text { cal BC }(68,2 \%) \text {; } \\
4950-4720 \text { cal BC }(95,4 \%)\end{array}$ \\
\hline & & & $3 a 2$ & $\begin{array}{l}\text { VERA-3535: } 5050-4850 \text { cal BC }(68,2 \%) \\
5210-4830 \text { cal BC }(95,4 \%) \\
\text { VERA } 3097: 4900-4780 \text { cal BC }(68,2 \%) ; \\
4940-4720 \text { cal BC }(95,4 \%)\end{array}$ \\
\hline & & & 3a1 & No data \\
\hline 5500-5000 cal BC (Oross and Bánffy, 2009) & Middle Neolithic (Linearband Pottery culture, LBK) & 2nd habitation phase & & No data \\
\hline 6000/5900-5500 cal BC (Kalicz, 2007) & Early Neolithic (Starčevo culture) & 1st habitation phase & & No data \\
\hline
\end{tabular}


Table 2

Radiocarbon dates from the sites at Sormás-Török-földek, Sormás-Mántai-dülő, Southwestern Hungary (P. Barna and Pásztor, 2011)

\begin{tabular}{|c|c|c|c|c|c|c|c|}
\hline \multirow[t]{2}{*}{ Name of the site } & \multirow[t]{2}{*}{ Code } & \multirow[t]{2}{*}{$\mathrm{BP}$} & \multicolumn{2}{|c|}{ Calibrated ages (cal BC) } & \multirow[t]{2}{*}{ Sample } & \multirow[t]{2}{*}{ Archaeological feature } & \multirow[t]{2}{*}{ Bibliography } \\
\hline & & & $1 \delta(68.2 \%)$ & $2 \delta(95.4 \%)$ & & & \\
\hline Sormás-Török-földek & VERA-3538 & $5855+/-35$ & $4780-4690$ & $4830-4610$ & Animal bone & Feat. 93 (Lengyel), pit & P. Barna (2007a,b, 367) \\
\hline Sormás-Török-földek & VERA-3539 & $5865+/-40$ & $4790-4700$ & $4840-4610$ & Animal bone & Feat. 376 (Sopot), pit & P. Barna (2007a,b, 367) \\
\hline Sormás-Török-földek & VERA-3098 & $5970+/-35$ & $4910-4790$ & $4950-4720$ & Animal bone & Feat. 376 (Sopot), pit & P. Barna (2007a,b, 367) \\
\hline Sormás-Török-földek & VERA-3097 & $5950+/-35$ & $4900-4780$ & $4940-4720$ & Animal bone & Feat. 259 (Sopot), pit & P. Barna (2007a,b, 367) \\
\hline Sormás-Török-földek & VERA-3535 & $6065+/-45$ & $5050-4850$ & $5210-4830$ & Animal bone & Feat. 259 (Sopot), pit & P. Barna (2007a,b, 367) \\
\hline Sormás-Mántai-dűlő & VERA-3101 & $5985+/-35$ & $4940-4800$ & $4990-4780$ & Animal bone & Feat. 202 (Sopot), pit & P. Barna (2007a,b, 367) \\
\hline Sormás-Mántai-dűlő & VERA-3103 & $6045+/-50$ & $5010-4840$ & $5200-4790$ & Animal bone & Feat. 369 (Sopot, House 7), pit & P. Barna (2007a,b, 367) \\
\hline Sormás-Mántai-dűlő & VERA-3102 & $6115+/-35$ & $5210-4980$ & $5210-4940$ & Animal bone & Feat. 316 (Sopot, House 4), pit & P. Barna (2007a,b, 367) \\
\hline Sormás-Mántai-dűlő & VERA-3099 & $6200+/-35$ & $5220-5070$ & $5300-5040$ & Animal bone & Feat. 53 (TLPC, Keszthely group), pit & unpublished \\
\hline Sormás-Mántai-dűlő & VERA-3100 & $6325+/-40$ & $5360-5220$ & $5470-5210$ & Animal bone & Feat. 108 (TLPC, older phase), pit & unpublished \\
\hline
\end{tabular}

find material of both Starčevo settlements can be dated to the beginning of the late phase of the culture (beginning of the Spiraloid B phase) (P. Barna, 2004). The following habitation phase belongs to the Keszthely group of the LBK (2nd habitation phase; 5500-5000 cal BC). Only a few settlement features of this phase could be identified.

The Late Neolithic period of the site can be divided into two phases. The 3rd inhabitation phase ( $5000-4500$ cal BC) is made up by the settlement of the Sopot culture. There were at least three inhabitation phases of the Sopot culture in the Török-földek site (settlement phases 3a1, 3a2 and 3b) (P. Barna, 2010). The longer duration of the settlement of the Sopot culture may be attested by a relatively greater diversity of house types. Not only single places of houses could be determined, but some household clusters consisting of the unity of a dwelling and a smaller, accompanying building of probably economic function. The inhabitation is concentrated in the inner territory of enclosure No. II (P. Barna, 2010). The 4th inhabitation phase ( $4900-4700 \mathrm{cal} \mathrm{BC}$ ) corresponds to the settlement of the Lengyel culture. The 3rd and the 4th inhabitation phase are connected strongly to each other, just like both cultures. The cultural and chronological connections between the 3rd and the 4th inhabitation phase are reflected in the context of the two enclosures in the same way as in the material culture. As it is attested by the find material (first of all the pottery) it is not possible to draw a categorical dividing line between the Sopot and Lengyel cultures.

The 4th habitation level is constituted by the formative and the early phase of the Lengyel culture (sub-phases $4 \mathrm{a}$ and $4 \mathrm{~b}$ ), which was also significant, similarly to the preceding Sopot-settlement. This is proven not only by the establishment of the northern enclosure (Enclosure No. I, Fig. 2), groups of houses and the abundance of the find material, but also by the fact, that it is one of the biggest, central-type settlement of the formative phase of the Lengyel culture.

The earlier sub phase (sub-phase $4 \mathrm{a}$ ) can be identified chronologically and culturally as the formative phase of the Lengyel culture or Lengyel 1a phase (Kalicz et al., 2007). Enclosure No. I was constructed in that time and was used only in this settlement phase. The dwellinghouses of this inhabitation phase were built still inside Enclosure No. II. The early Lengyel culture settlement is supposed to be long lasting and it may be presumed that it survived the initial phase of the culture (sub-phase 4b). This means that the youngest features of the settlement may be dated to the transition between Lengyel la and Ib phases (or even the beginning of Lengyel Ib phase).

The elimination of Enclosure No. I - by the homogenous filling - was the result of a conscious levelling and not a longer, natural filling in process. However, its reason is unknown, due to lack of clues for the possible causes for abandoning the settlement. It can be stated with certainty that as the whole life of the settlement was characterised by a longer, uninterrupted development, its end was neither caused by hostile attack, nor by the appearance of foreign ethnic groups. No traces of destruction layers or unburied bodies were found, which could indicate warfare. The early Lengyel period was followed by a several hundred year-long habitation hiatus, the end of which is indicated by a short habitation phase of the Middle Chalcolithic Balaton-Lasinja culture represented by a few settlement features.

\section{Material and methods}

\subsection{Charcoal analysis}

During the archaeological excavation preceding the M7 motorway macrobotanical material was obtained from the archaeological site Sormás-Török-földek. Sediment profiles were created (Sümegi et al., 2011a) at the archaeological sites and it was possible to study the settlement levels of the individual cultures and soil horizons.

Charcoal remains collected at the site originate from different archaeological features, amongst which there are refuse pits, extremely large pits used for clay mining, diverse structural elements of houses such as postholes and foundation trenches, ditches encircling houses (or building sites of dwelling-houses) and the ditches of the enclosures.

The archaeobotanical material was obtained from uniformly $2.7 \mathrm{~kg}$ of samples (Sümegi et al., 2011a) according to the German standards (Jacomet and Kreuz, 1999). The double flotation method of Gyulai (2001) was adopted, using 0.5 and $0.25 \mathrm{~mm} \emptyset$ mesh size sieves. Material is initially passed through the $0.5 \mathrm{~mm}$ mesh size sieve. The residue is then passed through the next sieve of smaller mesh size to retrieve smaller size remains as well.

The remains were then sorted for archaeological, archaeozoological and archaeobotanical analysis. Macrobotanical analysis was carried out on charcoals and seeds alone. Charcoal samples were selected and counted. We represent the charcoal fragment counts after Chabal et al. (1999). In case of floated samples it makes no difference if we count or weigh the amount of charred wood remains (Asouti and Austin, 2005).

Charcoals were identified using polarisation microscope with magnifications $100 \times, 200 \times$ and $500 \times$. The taxon identification was carried out using the reference books of Pál Greguss $(1945,1972)$ and Fritz Hans Schweingruber (1990).

The age of the charcoal samples were obtained according to the archaeological findings. The most precisely dateable features are the refuse pits and the foundation trenches of houses (if they contain datable artefacts). The extremely large pits used for clay mining, ditches encircling houses or building sites of dwelling-houses and the ditches of the enclosures are less appropriate for accurate dating regarded that they were opened and used for longer time. These features are large and deep in general, several times they have more than ten excavating layers. Samples taken from such large features can be dated precisely only if they originate from an unequivocally datable layer.

\subsection{Pollen analysis}

In order to get a more accurate vegetation reconstruction the pollen analytical data of Juhász $(2004,2007)$ were adopted and the results of 


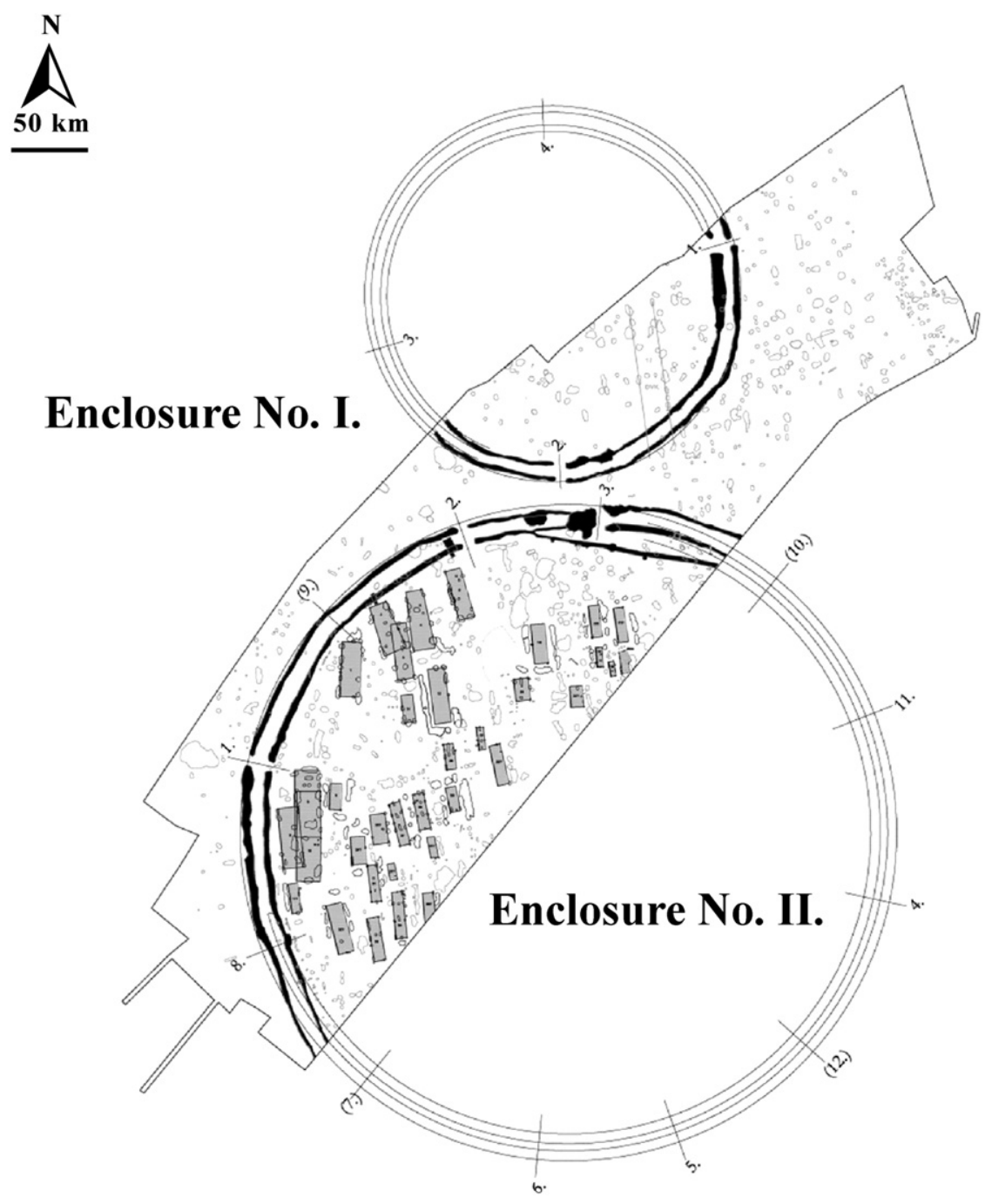

Fig. 2. Enclosures No. I and II. at Sormás-Török-földek (P. Barna, 2007a).

anthracological analysis was compared to the pollen sequence of Zalavár as it is the closest undisturbed core to the archaeological site where pollen analysis was performed (Fig. 3).

\subsection{Radiocarbon analysis}

The radiocarbon dates (Table 2) obtained from the sites at SormásMántai-dülő and Sormás-Török-földek compared to more data from other sites from the region has already been published (P. Barna, 2007a; P. Barna and Pásztor, 2011). The majority of the dates fall into the periods of the Sopot culture and to the formative phase of the Lengyel culture. Two data refer to the LBK. One date refers to the older phase of the LBK, another one to the Keszthely-group. Both dates of the LBK diverge clearly from the others and are in good concordance with data published recently by Oross and Bánffy (2009). The dates referring to the Sopot and the Lengyel cultures are very close to each other; some of the Sopot dates cover those of the Lengyel culture. This problem was recognized also in other sites in Southwestern Transdanubia (Kalicz et al., 2007). Out of the dates overlying each other only the oldest dates of the Transdanubian Sopot culture hang out, which go back to the end of the 6th millennium BC. As for dates referring to the formative phase of the Lengyel culture we used a single date obtained from Sormás-Török-földek (Feat. 93), which fits in the time period indicated by the sequence of 7 data of the Esztergályhorváti common grave of the same time range (P. Barna, 1996; Bronk-Ramsey et al., 1999; Stadler and Ruttkay, 2007).

\section{Results of charcoal analysis}

The total number of samples deriving from the features of the archaeological excavations is 239. The total volume of samples was $75,697 \mathrm{~cm}^{3}$. However, the anthracological material of 123 samples was unidentifiable due to bad preservation or overburning of charcoal fragments or origin from undated archaeological features. Thus the number of samples containing identifiable charcoal fragments is 116 . Results of anthracological analyses are presented in Table 3 as counts and percentage ratio of charcoal fragments. The total amount of identified charcoal fragments is 3693 with 6 identified genera and 1 group that was defined as Pinaceae due to bad preservation.

Charcoal fragments deriving from the 1st habitation phase (Starčevo; 6000/5900-5500 cal BC) indicate Quercus dominance. However the total amount of charcoal derives from this archaeological horizon is low (132 pieces of fragments). Unfortunately, no charcoals were retrieved from archaeological features belonging to the 2nd habitation phase (55005000 cal BC).

The total number of charcoal fragments deriving from the 3rd habitation phase (Sopot culture; $5000-4500 \mathrm{cal} \mathrm{BC}$ ) is 1746 pieces. It indicates a very high Quercus ratio of $90.5 \%$. In addition charred wood remains of Pinaceae, Fagus, Fraxinus, Ulmus and Alnus were found. 


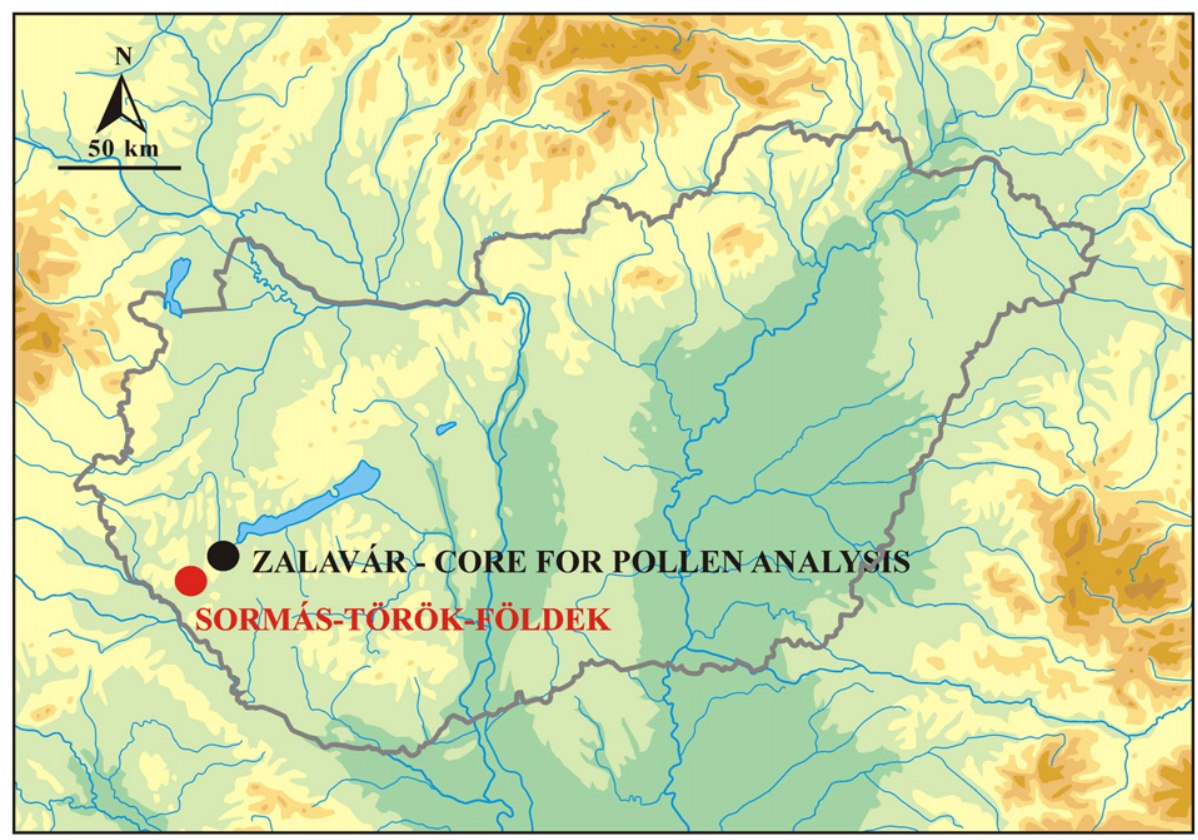

Fig. 3. Location of Sormás-Török-földek (red square) and the core for pollen analysis (black square).

A total of 1815 pieces of fragments turned up from archaeological features belonging to the period of the 4th habitation phase (Lengyel culture; 4900-4700 cal BC). It points to Quercus dominance as well, however, its ratio decreased to $81 \%$. Besides the remains of oak, Acer, Alnus, Fagus, Ulmus and Fraxinus charred wood remains occurred.

Tables 4 and 5 present charcoal distribution with regard to archaeological features. It can be clearly seen that during the 3rd habitation phase (Table 4) Alnus, Fagus, Fraxinus and Quercus are found in refuse pits, while Quercus and Ulmus are mainly confined to extremely large pits used for clay mining. Fagus, Pinaceae and Quercus charcoals occur in diverse structural elements of houses, Quercus appear in ditches encircling houses and in the ditches of the enclosure.

During the 4th habitation phase (Table 5) Acer, Alnus, Fagus, Quercus and Ulmus occur in refuse pits and Quercus in extremely large pits used for clay mining as well. Alnus and Quercus appear in diverse structural elements of houses, such as postholes. Acer and Quercus are found in the ditches of the enclosure, while Acer, Fraxinus and Quercus appear in a scarify pit as well.

\section{Discussion of the vegetation cover during the Neolithic around Sormás-Török-földek}

\subsection{Discussion of the charcoal results with the archaeological background}

Charcoal fragments deriving from the 1st habitation phase (Starčevo culture) that were disturbed later by new settlers of the Sopot and
Lengyel culture point to Quercus prevalence (Fig. 4). However, only a small amount of charcoal occurred in features of these periods. Probably two other archaeological features that contained only ash and charcoal belong to this period as well, although their dating is problematic due to the lack of ceramics.

We have no data regarding the 2 nd habitation phase since charcoal fragments did not occur in closed archaeological features that belong surely to LBK.

Most of the analyzed samples belong to the 3rd and 4th habitation phases. Six different genera were found in archaeological features of the 3rd habitation phase of the Sopot culture. $90.5 \%$ of charred wood remains belong to Quercus; besides Fagus, Ulmus, Pinaceae, Alnus and Fraxinus. The high number of Quercus charcoal and their source archaeological features (refuse pits, structural elements, and ditches) indicate that it was available in large quantities in the surroundings of the settlements and was used for fuel wood and construction purposes as well. Fagus remains occurred in diverse structural elements of houses and in refuse pits so it was used as construction wood and fuel wood. Pinaceae occurred in diverse structural elements so it might was construction wood. Alnus and Fraxinus appeared in refuse pits indicating its utilization as fuel wood. Moreover, Alnus also turned up in extremely large pits used for clay mining, such as Ulmus indicating their role as firewood.

The 4th habitation phase indicates Quercus dominace similarly to the previous phase although with a lower ratio (81\%). Based on the source archaeological features (refuse pit, extremely large pit used for clay

Table 3

Summary of absolute and percentage fragment counts of charcoal fragments at the rescue excavation of Sormás-Török-földek

\begin{tabular}{|c|c|c|c|c|c|c|c|c|c|}
\hline \multirow[t]{2}{*}{ Charcoal taxa } & \multicolumn{2}{|c|}{$\begin{array}{l}\text { 1st habitation } \\
\text { phase }\end{array}$} & \multicolumn{2}{|c|}{$\begin{array}{l}\text { 2nd habitation } \\
\text { phase }\end{array}$} & \multicolumn{2}{|c|}{$\begin{array}{l}\text { 3rd habitation } \\
\text { phase }\end{array}$} & \multicolumn{2}{|c|}{$\begin{array}{l}\text { 4th habitation } \\
\text { phase }\end{array}$} & \multirow[t]{2}{*}{ Total number } \\
\hline & No. & $\%$ & No. & $\%$ & No. & $\%$ & No. & $\%$ & \\
\hline Acer & & & & & & & 200 & 11 & 200 \\
\hline Alnus & & & & & 21 & 1.2 & 8 & 0.4 & 29 \\
\hline Fagus & & & & & 62 & 3.5 & 56 & 3.1 & 118 \\
\hline Fraxinus & & & & & 16 & 0.9 & 32 & 1.8 & 48 \\
\hline Pinaceae & & & & & 30 & 1.7 & & & 30 \\
\hline Quercus & 132 & 100 & & & 1580 & 90.5 & 1471 & 81 & 3183 \\
\hline Ulmus & & & & & 37 & 2.2 & 48 & 2.7 & 85 \\
\hline Number of identified charcoal fragments & 132 & & - & & 1746 & & 1815 & & 3693 \\
\hline
\end{tabular}


Table 4

Archaeological features and fragment counts of genera during the 3rd habitation phase.

\begin{tabular}{|c|c|c|c|c|c|c|c|}
\hline \multicolumn{8}{|l|}{ 3rd habitation phase } \\
\hline & Alnus & Fagus & Fraxinus & Pinaceae & Quercus & Ulmus & Total number \\
\hline Refuse pits & 17 & 2 & 16 & & 508 & & 543 \\
\hline Extremely large pits used for clay mining & 4 & & & & 607 & 37 & 648 \\
\hline Diverse structural elements of houses (postholes and foundation trenches) & & 60 & & 30 & 202 & & 292 \\
\hline Ditches encircling houses (or building sites of dwelling-houses) & & & & & 158 & & 158 \\
\hline Ditches of the enclosures & & & & & 105 & & 105 \\
\hline Total number & 21 & 62 & 16 & 30 & 1580 & 37 & 1746 \\
\hline
\end{tabular}

mining, diverse structural elements of houses, ditches encircling houses, ditches of the enclosure and in a sacrify pit), it was used as construction wood and fuel wood similarly to the 3rd habitation phase. Similar wood genera occurred to that in the 3rd phase, with the only exception of the absence of Pinaceae and the presence of Acer. This later turned up in refuse pits, in the ditches of the enclosure and in a sacrify pit. Half of the samples of Acer appeared in the late phase of the 4th habitation phase (P. Barna, 2010). Moreover, all of the archaeological features where Acer charcoal occurred is located in the vicinity of Enclosure No. I that indicate also the late phase of the 4th habitation phase.

Fagus and Ulmus turned up in refuse pits so they might have been utilized as fuel wood. Alnus appeared in a low ratio in a posthole indicating its utilization as construction wood and in a refuse pit. Fraxinus derive from one archaeological feature that belong to the late phase of the 4th habitation phase that presumably was used for a ritual activity (P. Barna, 2010). The structure of this archaeological feature was continuous and its charcoal and ash filling, rich and unique findings (anthropomorphic figurines, askos, bucranium) may point iterative ritual act of burning. Fraxinus, Quercus and Acer (from top to bottom) appeared in different layers of the feature but they all belong to the late phase of the 4th habitation phase. Potential connections between the ritual use of the object and the presence of tree species (Acer, Farxinus and Quercus) is a question of debate.

\subsection{The comparison with the regional pollen record and the on-site} archaeobotanical material

Palynological results (Figs. 5 and 6, after Juhász, 2004, 2007) indicate Quercus dominance similarly to the anthracological results, so deciduous oak woodland existed at the beginning of the Neolithic (6000 BC) in the study area. The increase of Betula and Pinaceae pollen coincide with the pre-Neolithic and the beginning of the Neolithic period. Pinus pollen peak may point to the spread of pines in the area. However, pine pollen grains have air sacks following that they can be transported over long distances. Pinus is a pioneer species that establish fast on cleared areas. The rise of Betula in the pollen diagram indicates deforestation beforehand and succession as it is also pioneer that can be spread easily and fast on cutoff areas (Jansen and Nelle, 2012) so cyclic forest burning may have occurred. Deforestation resulted in the opening up of the forest canopy where Corylus could spread on forest edges as the high value of Corylus pollen indicates (Willis et al., 1997, 1998; Magyari et al., 2002; Sümegi, 1998, 2004a, 2013; Sümegi et al., 2004;
Juhász, 2007). Its ratio is cyclic and is in contradiction with Quercus pollen ratio. Other study of this site (Juhász, 2004) indicates high ratio of Pteridium spore in the profile between $255-200 \mathrm{~cm}$ that corresponds to the period between $6600-6160 \mathrm{cal} \mathrm{BC}$ and $6220-6020 \mathrm{cal}$ BC (95.4\%) (Juhász, 2004). This can be interpreted as a "preneolithic human influence" (Juhász, 2004) that resulted in the opening up of the forest canopy.

Charcoal data of the 3rd and 4th habitation phases (Middle and Late Neolithic) correlates well with pollen analytical data, some differences derive from the regional nature of pollen which may hide distinct local vegetation characteristics. Differences relate to the absence of Corylus, Tilia and Carpinus charcoals that are present in the pollen material. The lack of Tilia in the charcoal assemblage is not surprising as it is unsuitable as fire wood (Kreuz, 1992). However, in other Neolithic sites in Germany (Jansen and Nelle, 2012) Tilia is well represented. Carpinus is rather sporadic in the pollen diagram and probably was sporadic also in the forest stand, as well as Tilia. The reason for the high amount of Corylus pollen is may be its fast growth and its ability to produce shoots after cutting (Jansen and Nelle, 2012) such as Quercus and/or the abovementioned forest burning activity. However, neither Corylus charcoals nor fruits have been found in this area yet.

Pollen of herbaceous plants such as Artemisia, Compositae and Chenopodiaceae indicates human activity. Pollen of cereals appeared only in the Copper age, however cereal seeds were found in SormásTörök-földek site. Triticum monococcum (10 pieces), Triticum dicoccum (41 pieces), Triticum spelta (5 pieces) and Hordeum vulgare (5 pieces) appeared. Further cultivars such as Pisum sativum (3 pieces), Lens culinaris (5 pieces) and Linum usitatissimum (36 pieces) seeds occurred from Neolithic features (Sümegi, 2007b). Besides these, 287 pieces of fragments that belong to cultivated cereals (Gramineae cultae) occurred. However, their genus or species identification was not possible. Weeds indicating cultivated lands, roads and settlements appeared, such as Chenopodium album and Sambucus racemosa. The presence of Bromus secalinus supports the cultivation of cereal since it indicates cultivated area even if cereal pollen or seeds do not occur. Ononis spinosa seeds were also found that point to animal husbandry. So besides plant cultivation, livestock farming was present in the Neolithic settlement (Sümegi, 2007b).

Intensive deforestation is characteristic only from the Copper age, since the ratio of NAP (non-arboreal pollen) and the decrease of AP (arbour pollen) pollen occur from this period of time (Fig. 5, 140$150 \mathrm{~cm})$.

Table 5

Archaeological features and fragment counts of genera during the 4th habitation phase.

\begin{tabular}{|c|c|c|c|c|c|c|c|}
\hline \multicolumn{8}{|l|}{ 4th habitation phase } \\
\hline & Acer & Alnus & Fagus & Fraxinus & Quercus & Ulmus & Total number \\
\hline Refuse pits & 137 & 6 & 56 & & 1001 & 48 & 1248 \\
\hline Extremely large pits used for clay mining & & & & & 65 & & 65 \\
\hline Diverse structural elements of houses (postholes and foundation trenches) & & 2 & & & 191 & & 193 \\
\hline \multicolumn{8}{|l|}{ Ditches encircling houses (or building sites of dwelling-houses) } \\
\hline Ditches of the enclosures & 24 & & & & 179 & & 203 \\
\hline Sacrifice pit & 39 & & & 32 & 35 & & 106 \\
\hline Total number & 200 & 8 & 56 & 32 & 1471 & 48 & 1815 \\
\hline
\end{tabular}




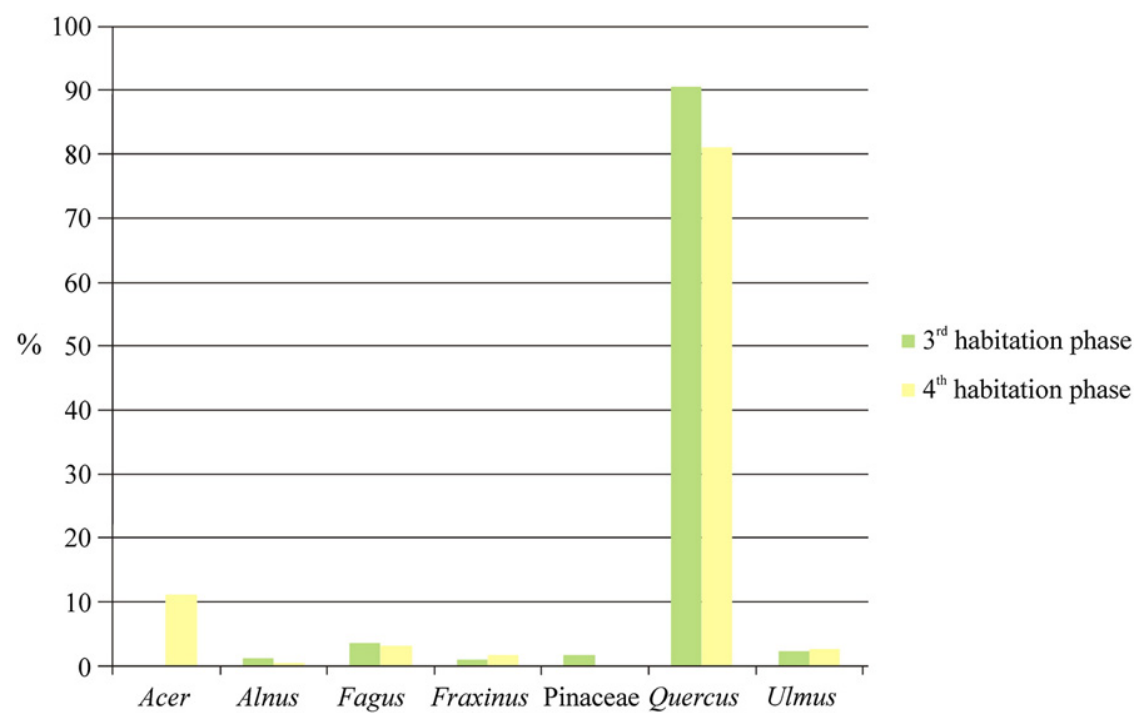

Fig. 4. The comparison of charcoal occurrence in habitation phases 3 and 4 .

\subsection{Wood selection and taphonomy}

The large number of Quercus charcoal raises questions regarding the selection of wood and fragmentation of charcoal. The composition of charcoal assemblage and the relative frequencies of taxa do not necessarily indicate the composition of past vegetation (Figueiral Mosbrugger, 2000). Rather, it provides data regarding the taxa used by human population (Willcox, 2002). Therefore the influence of human selection must be considered. Fuel wood for domestic purposes is generally collected from the nearest resources (principle of least effort), so the charcoal composition reflects the availability of the surroundings of settlements (Shackleton and Prins, 1992). Based on this, availability is the principal factor regarding domestic firewood selection (Chabal, 1992). On the contrary, construction purposes demanded specific wood selection (Western, 1971). However, it is assumed that for the Neolithic the charcoal assemblage represents the available wood in the vicinity of the settlements (Jansen and Nelle, 2012). In view of fragmentation after Chabal (1997) the fragmentation process of charcoal is the same for all species in the case of

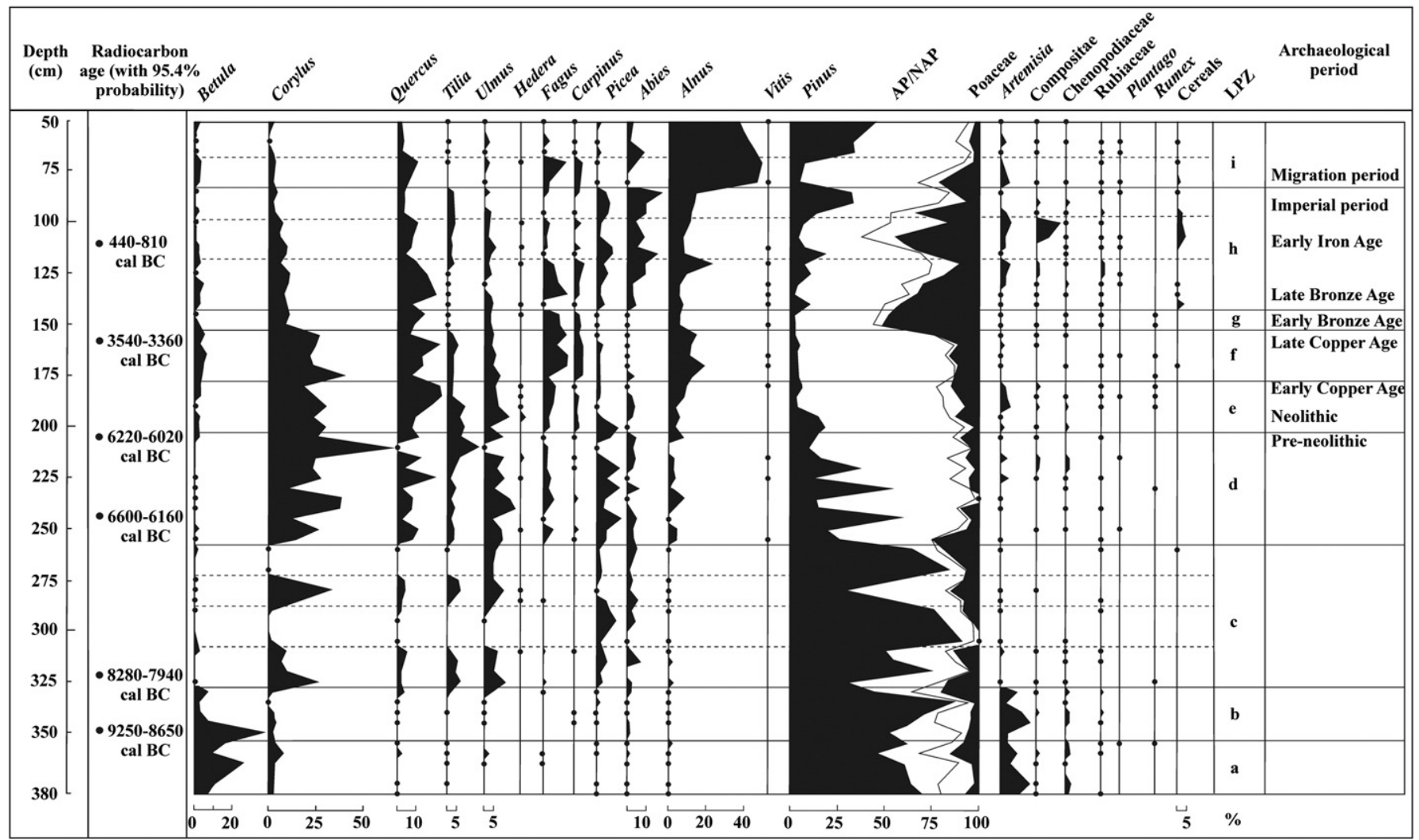

Fig. 5. Pollen analytical results of Zalavár (adopted and modified after Juhász, 2007). 


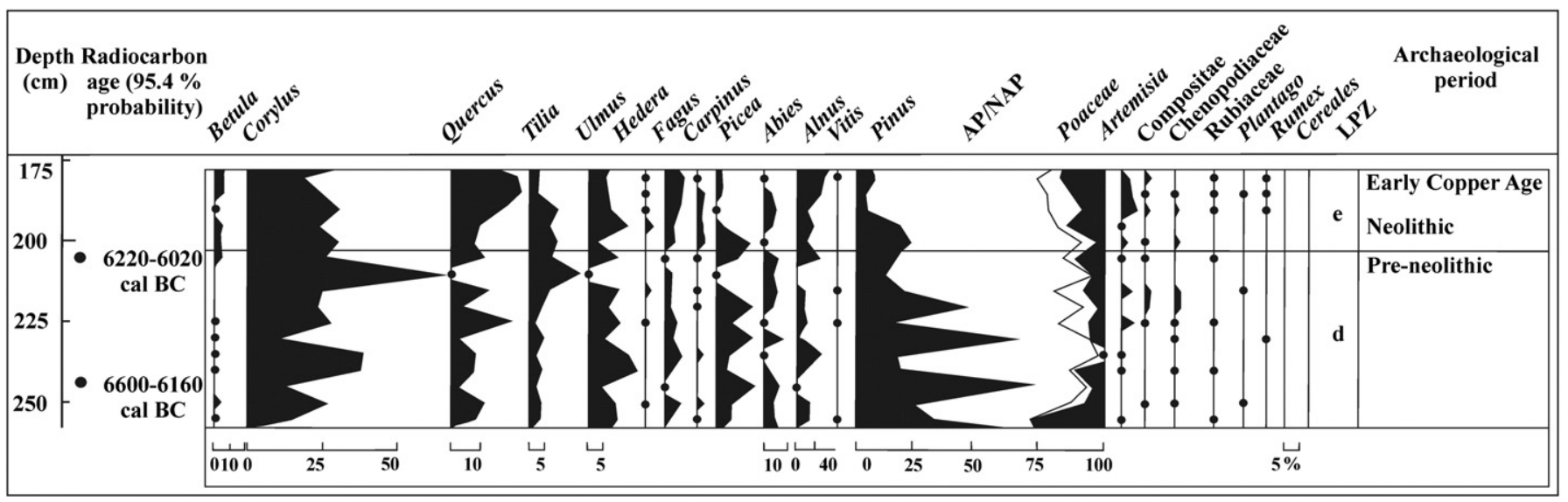

Fig. 6. Pollen analytical results of Zalavár with Local Pollen Zones d and e (adopted and modified after Juhász, 2007).

archaeological material. Moreover, she did not find significant differences in the fragmentation of Quercus, Ulmus and Alnus (Chabal, 1992). Vertical movements that cause the mixing of archaeological levels was not observable, however we can not exclude bioturbation.

6.4. Review of Fagus colonisation into the study area in the light of the new results

Fagus charcoals are very important since their local presence indicate that Fagus trees existed in the region already in the Neolithic (Sümegi et al., 2011b). After Lang (1994) the spread of Fagus into Central Europe coincided with the Neolithic. In the study area Fagus charcoals are present from the Middle to the Late Neolithic and the pollen ratio of Fagus increase continuously from the 7th millennium BC and has a high significance. Hungarian palynologists (Juhász, 2002; Magyari, 2001) explain the time transgressional development of the pollen horizon of both species in the Carpathian Basin with migration processes. Furthermore both Hungarian palynologists (Juhász, 2002; Magyari, 20'01) originate the Fagus forests of the Carpathian Basin from the Fagus refugium of Slovenia, meaning that the origin of Fagus forests in Transdanubia, the North Hungarian Range and the Great Hungarian Plain resulted from this single Slovenian refugium. This one-centred beech colonisation model could be refused almost in the first moment it appeared by the radiocarbon dating of late glacial and Early Holocene pollen data of the Lake Balaton and Nagybárkány (Sümegi, 2005, 2007a; Jakab et al., 2009; Sümegi et al., 2009) and also by the late glacial Rejtek (Sümegi, 2007a) and Early Holocene Great Hungarian Plain (at Bátorliget) beech charcoal data (Sümegi, 2004b), both with radiocarbon dating (Fig. 7). The appearance of Fagus (and Carpinus) pollen in the study area and in the section is much earlier than it could be expected by the beech colonisation model. These data are well-paralleled with the results of pollen analyses carried out in the Austrian side of the foreland of the Eastern Alps and in Burgenland (Drescher-Schneider, 2004). The refugium of beech at the end of the glacial period probably consisted of many diffused patches (Magri et al., 2006; Magri, 2008; Brus, 2010), starting at the foreland of the Alps in Slovenia through the foreland of the Eastern Alps, all the way to the southern foreland of the Transdanubian Mountain Range. Besides this

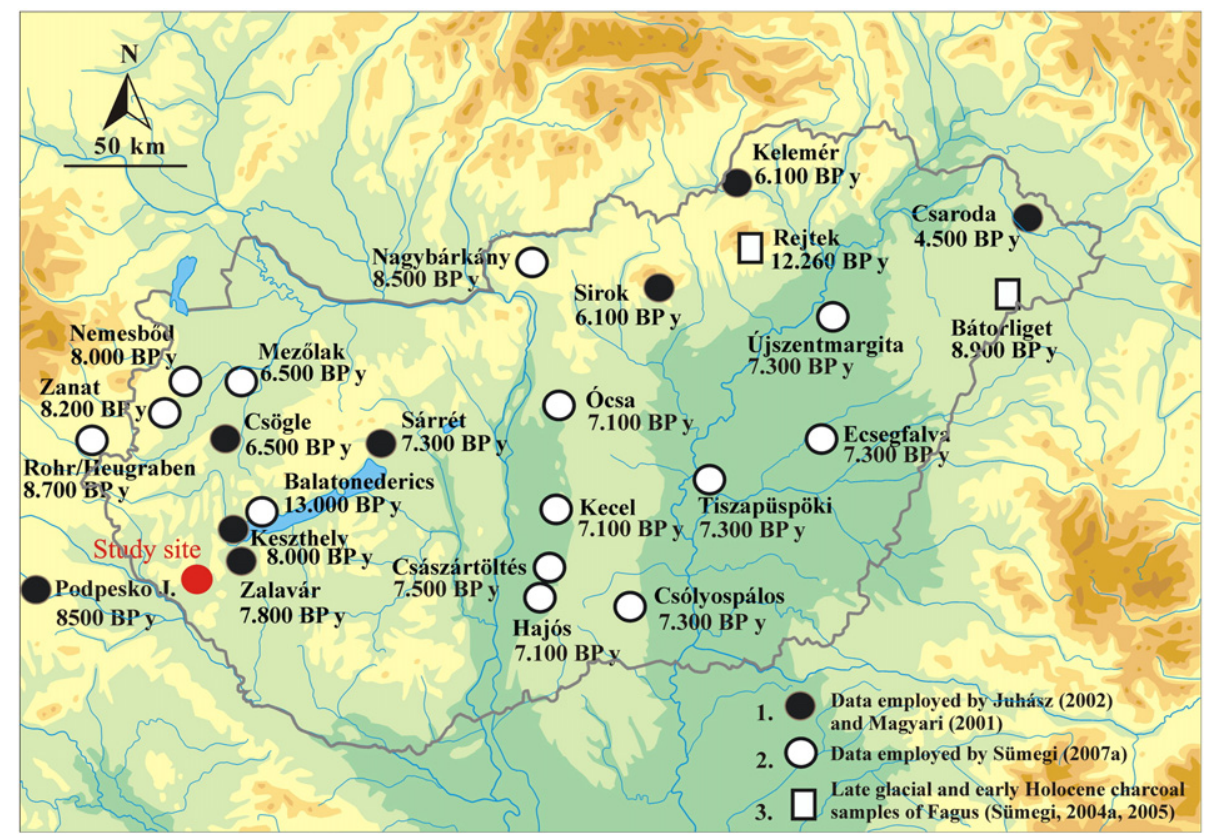

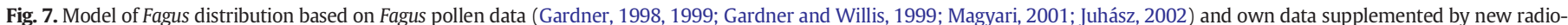

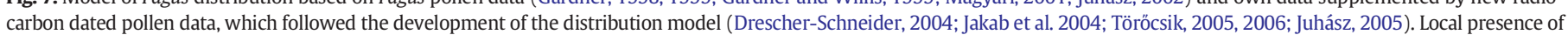
Fagus supplemented by charcoal samples (Stieber, 1964, 1967; Rudner et al. 2004; Sümegi, 2004a). 
Praenoricum and Praeillyricum refugium region another independent Fagus refugium may have existed in diffuse patches in the western part of the Carpathian Basin, in the North Hungarian Range and in the eastern side of the Munţii Apuseni (Sümegi, 2004b, 2007a). The Middle Neolithic macroscopic charcoal fossils of Fagus may prove that an independent forest development characterised the western and southwestern part of Transdanubia and the existence of a Fagus refugium in the area. These data might support the existence of a "cryptic refugia" (Birks and Willis, 2008 ) in the area. It "refers to restricted refugia comprising areas with sheltered topography and buffered, stable local microclimates (Stewart and Lister, 2001) that are too localised or small to be detected by pollen analysis" (Birks and Willis, 2008).

\subsection{Woodland reconstruction around the site}

Relying upon the above mentioned facts (Shackleton and Prins, 1992; Chabal, 1997), previous statements (Jansen and Nelle, 2012) and the results of anthracological and palynological data we suppose that the anthracological data represents the wood taxa that were originally in the forest regarding arboreal species surrounding the study site. However, the selection of Quercus cannot be excluded. At the same time it was certainly the most abundant taxa in the forest around the Neolithic settlement.

The arboreal vegetation cover of the 1 st and 2 nd habitation phase cannot be reconstructed on the basis of anthracological analysis since only a little amount of charcoal turned up from Starčevo archaeological features (1st habitation phase) and none from the 2nd phase. However, the overburned charcoal material and ash filling of archaeological features of the 1st habitation phase (Starčevo culture) indicate human activity already during Early Neolithic. Moreover, palynological record also point to deforestation even during pre-Neolithic (Juhász, 2004). The rise of Betula and Pinus pollen and the cyclic change of Corylus (Juhász, 2004, 2007) indicate forest burning beforehand and the opening up the forest canopy. On the basis of pollen data a thermophilous Quercus dominated forest subsisted in the southwestern Transdanubian region.

Anthracological material from the Middle Neolithic gave appreciable results regarding arboreal vegetation. According to these results a deciduous thermophilous forest with Quercus, Fagus, Ulmus, and Fraxinus surrounded the former human settlement during the 3rd habitation phase of the Middle Neolithic, during the time period of the Sopot culture. Species of Pinaceae may exist on higher elevations and/or colder valleys.

During the time period of the 4th habitation phase (Lengyel culture) the thermophilous forest still existed around the settlement, indicating Quercus dominance mixed with Acer, Fagus Ulmus and Fraxinus. On wet surfaces or riversides Alnus trees appeared.

The present forest associations such as Vicio oroboidi - Fagetum and Fraxinus pannonicae - Ulmetum may have existed already during Middle and Late Neolithic. Nevertheless this latter was mixed with pine trees during the Middle Neolithic. Probably due to human impact such as deforestation, the decrease of moisture and the increase of temperature, the number of pine trees was reduced and during Middle Neolithic they disappeared from the forest assemblage. In fact, pine charred wood remains have not occurred from the later archaeological phase of the site. Probably the recent Querco-Ulmetum forest association developed as a result of human activity at the end of the Neolithic.

\section{Conclusions}

The importance of the archaeological site at Sormás-Török-földek lies in the fact that it provided a favoured unique opportunity to study the formation process of the Late Neolithic Lengyel culture. Besides the find material from the Sopot culture, one of the basic components of the Lengyel culture, the find material from the formative phase of the Lengyel culture was also found on the site. The formation process of the Lengyel culture could be studied through the comparisons of the find material and the settlement structures of both cultures.
The determination of the habitation phases and examination of the finds belonging to a given habitation phase made it clear that in habitation phase 3 (Sopot culture) and 4 (Lengyel culture) a continuous development may be estimated, in spite of the cultural change from Sopot culture to Lengyel culture. The whole existence of the site at SormásTörök-földek indicates a long, peaceful development, which, based on radiocarbon data, lasted at least for 400 years. It is not known, what put an end to the existence of the early Lengyel settlement, but there are not any perceptible traces of violent occupation, invasion or destruction. The same may be supposed for the whole area and age that were examined (P. Barna, in press).

Besides the archaeological findings large quantity of charcoal samples were collected and identified to help to reconstruct the local former vegetation during the Neolithic. During the excavation, samples for anthracological analysis were collected. Sormás-Török-földek site is the first Neolithic site in Southwestern Transdanubia where anthracological analysis was carried out so it has a high importance in terms of the study site and the archaeological period. The result of the charcoal analyses was compared to pollen data of the Zalavár core in the Little Balaton region (Juhász, 2007; Fig. 3) to provide a more exact vegetation reconstruction. Although Zalavár does not lie in the immediate environment of the site, it is suitable for a regional comparison. Pollen data (Juhász, 2007) and other environment historical records (Willis et al., 1997, 1998; Magyari et al., 2002; Sümegi, 1998, 2004a,b, 2013; Sümegi et al., 2004) indicate that humans were present in the study area already before Early Neolithic.

The volume of the anthracological material is notable. The total sum of charred wood remains is 3693 pieces that cover 6 genera and one group of Pinaceae.

The site and the anthracological material are both absolute and relative chronological dated. Based on radiocarbon data the age of the Middle Neolithic (Sopot culture) and Late Neolithic (formative/Early Lengyel culture) settlements can be dated between 5050-4850 (68.2\%); 5210-4830 (95.4\%), 4790-4700 (68.2\%); and 4840-4610 (95.4\%) cal BC years (Table 2).

The charcoal assemblage indicates that deciduous thermophilous oak forest with Fagus, Ulmus and Fraxinus existed during Middle Neolithic (3rd habitation phase) (Table 5). Fagus and pine trees may have existed on higher hill slopes or in cooler valleys, while the Quercus-Ulmus-Fraxinus dominated forest occupied the lower areas. Pinaceae disappeared during or at the end of the Middle Neolithic and appeared again only in Keszthely Mountains during Bronze Age. Probably due to the warming up of climate, deforestation and the opening up of the forest canopy, the number of pine trees decreased during the Middle Neolithic. The auto-flammability of pines will be extreme through higher temperature (Payette, 1992) and the destructive work of wood-beetles will be more intensive in an open space. So human activity induce a local ecosystem transformation. As a consequence of it, the number of thermosensitive and humidity sensitive species was reduced. The creation of human settlements, roads, cultivated lands and grazing fields involve deforestation and the abovementioned effects. In addition, construction purposes demanded large quantity of wood. The anthracological and archaeological results indicate that different wood types were used for construction purposes such as Quercus, Fagus and Pinaceae. Furthermore, Quercus and Fagus were utilized as fuel wood as well, such as Alnus, Fraxinus and Ulmus (Table 6).

During the Late Neolithic (4th habitation phase) the thermophilous forest still existed around the settlement, indicating Quercus dominance mixed with Acer, Fagus, Ulmus and Fraxinus. On wet surfaces or riversides Alnus trees appeared. The archaeological data indicate the utilization of Quercus, Acer and Alnus as construction wood and fuel wood. Ulmus was used as fuel wood as it appeared only in a refuse pit. Fraxinus derive from one archaeological feature from the late phase of the 4th habitation phase and presumably was used for ritual activity (P. Barna, 2010). The structure of the archaeological feature, its charcoal 


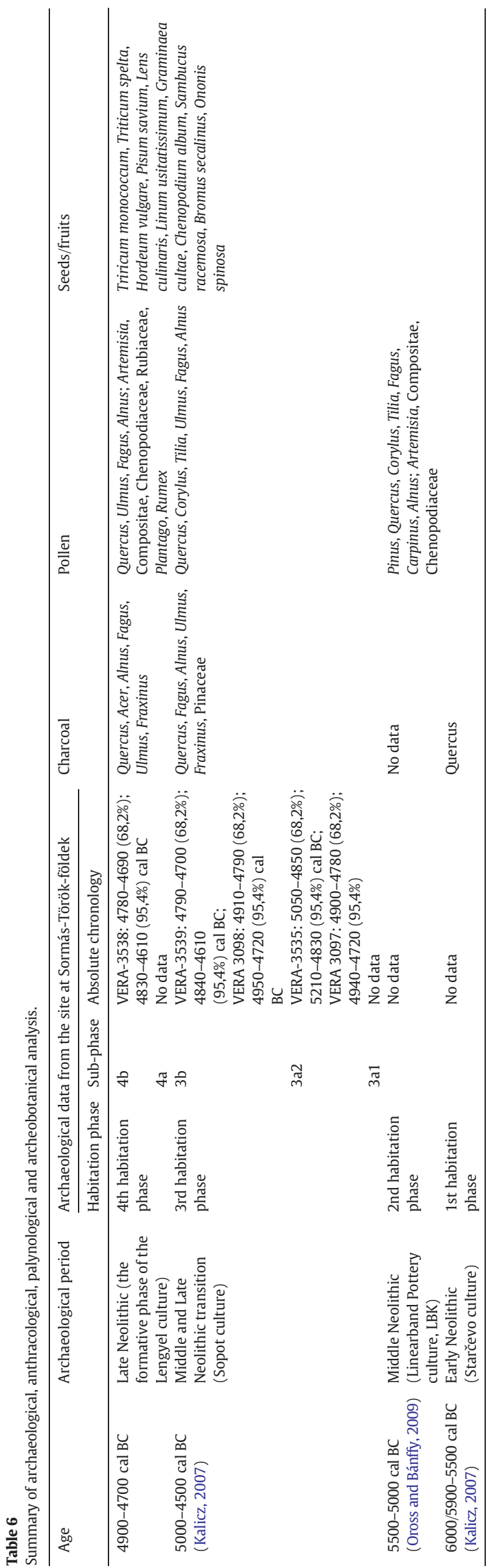

and ash filling, rich and unique findings may point to iterative ritual act of burning. However, the potential connections between the genera of wood (Acer, Fraxinus and Quercus) and the ritual use of the feature are still a question and the subject of further studies.

Besides charcoal fragments, pollen of herbaceous plants during Neolithic such as Artemisia, Compositae and Chenopodiaceae indicate human activity as well. Furthermore, seeds that turned up from the archaeological features indicate plant cultivation and animal husbandry. T. monococcum, $T$. dicoccum, $T$. spelta and $H$. vulgare seeds appeared. Further cultivars such as P. sativum, L. culinaris and L. usitatissimum seeds occurred (Sümegi, 2007b). Besides these, 287 pieces of fragments that belong to cultivated cereals (G. cultae) occurred. Weeds indicating cultivated lands, roads and settlements appeared, such as the presence of $C$. album, S. racemosa and B. secalinus support the cultivation of cereals. 0 . spinosa seeds point to animal husbandry, so besides plant cultivation, livestock farming was present in the Middle and Late Neolithic (Sümegi, 2007b).

The results of anthracological and palynological methods correlate well, some differences can be attributed to the different preservation of species, to burning qualities and to the regional nature of pollen which may hide distinct local vegetation characteristics.

The anthracological material originating from the Middle and Late Neolithic Sopot and Early Lengyel culture indicates unambiguous Quercus dominance. The wood of oak is valuable and workable hard wood that biological resistance is good due to its tannin content. It is durable and can be used for construction purposes and furniture making. Building remains found at the site suggest timber frame buildings with wattle and daub walls, amongst which we can found dwelling houses and buildings of other functions as well. Based on the more than 30 buildings, the enclosures and their related structure elements excavated on the site (palisades, wooden structures belonging to gates, wooden bridge), large-scale and wood-intensive construction activity can be concluded. So the dominance of Quercus in the charcoal assemblage most likely is the result of a conscious human selection, however its prevalence in the forest stand is unambiguous. This assumption is reinforced by the charcoal data indicating that except one sample where Acer was found, Quercus occurred from the objects of the enclosure.

The comparison shed light on the fact that while pollen data indicate Tilia and Carpinus presence in the region during Neolithic, they were not represented amongst charcoal remains derive form the archaeological site at Sormás-Török-földek. The wood of Tilia is soft and unsuitable for firewood (Kreuz, 1992), however at some places it occurred in large volumes (Jansen and Nelle, 2012). At the same time, it is easy to carve and ideal for furniture making and construction. Carpinus is an excellent raw for making tools as its wood is firm and hard. The absence of Tilia and Carpinus not necessarily indicate the selection of wood and as a consequence the avoidance of this two species in the forest stand. Due to the regional character of pollen and the distance between the archaeological site and the core location the lack of Tilia and Carpinus rather seems to indicate that they were not represented in the forests around the site. Our analysis and conclusions may be more accurate if a core closer to the study site could be performed.

The presence of Fagus charcoal is very important since their on-site remains indicate that Fagus trees existed in the region already in the Middle Neolithic that is very important regarding Fagus migration processes. Radiocarbon dated pollen and charcoal data from Hungarian sites (Sümegi, 2004b, 2005, 2007a; Jakab et al., 2009; Sümegi et al., 2009) indicate that the refugium of Fagus at the end of the glacial period probably consisted of many diffused patches (Magri et al., 2006; Magri, 2008; Brus, 2010) in the western part of the Carpathian Basin, in the North Hungarian Range and in the eastern side of the Munţii Apuseni in Romania (Sümegi, 2004b,a).

It can be stated that the anthracological analysis of Sormás-Törökföldek enabled a more accurate vegetation reconstruction for the study site by the comparison to previously known pollen analytical 
data and added extra information regarding the local vegetation and wood utilization for the Middle and Late Neolithic.

\section{Acknowledgment}

We express our gratitude to the excavators and workers of SormásTörök-földek and Sormás-Mántai-dűlő for the obtained archaeological, macrobotanical and anthracological material and Dr. Nándor Kalicz (Archaeological Institute of the Hungarian Academy of Sciences) for his indispensable help during processing the archaeological material of the site. Pál Sümegi's research was supported by the European Union and the State of Hungary, co-financed by the European Social Fund in the framework of TÁMOP-4.2.4.A/2-11/1-2012-0001 'National Excellence Program'.

\section{References}

Asouti, E., Austin, P., 2005. Reconstructing woodland vegetation and its exploitation by past societies, based on the analysis and interpretation of archaeological wood charcoal macro-remains. Environ. Archaeol. 10, 1-18.

Bánffy, E., 1995. South West Transdanubia as a mediating area. On the cultural history of the Early and Middle Chalcolithic. Archaeology and settlement history in the Hahót Basin, South-West Hungary. Antaeus 22, pp. 157-196.

Bánffy, E., 2004. Neolithic contacts: adaptation, exchange of information (an introduction). Antaeus 27, 11-16.

Bánffy, E., 2013. Tracing the beginning of sedentary life in the Carpathian Basin. The formation of the LBK house. In: Hoffmann, D., Smyth, J. (Eds.), Tacking the Neolithic House in Europe. One World Archaology, New York, pp. 117-149.

Bánffy, E., Oross, K., 2010. The "earliest" and the "earlier" phase of the LBK in Transdanubia. In: Gronenborn, D., Petrasch, J. (Eds.), The spread of Neolithic to Central Europe. RGZM Tagungen, Bd. 2. Mainz, pp. 255-272.

Bánffy, E., Marton, T., Osztás, A., 2010. Early neolithic settlement and burials a Alsónyék-Bátaszék. First report. In: Kozlowski, J.K., Raczky, P. (Eds.), Neolithisation of the Carpathian Basin: Northernmost distribution of the Starcevo/Körös culture Poligrafia Inspektoratu Towarzystwa Salezjańskiego, Kraków-Budapest, pp. 37-51.

Birks, H.J.B., Willis, K.J., 2008. Alpines, trees, and refugia in Europe. Plant Ecol. Divers. 1 (2), $147-160$.

Biró, K., 2003. The Neolithic. In: Visy, Zs. (Ed.), Hungarian Archaeology at the Turn of the Millenium. Ministry of National Cultural Heritage, Teleki László Alapítvány, pp. 98-121.

Bronk-Ramsey, C., Pettit, P.B., Hedges, R.E.M., Hodgins, G.W.L., 1999. Radiocarbon dates from the AMS system: datelist 27. Archaeometry 41 (1), 197-206.

Brus, R., 2010. Growing evidence for the existence of glacial refugia of European beech (Fagus sylvatica L.) in the south-eastern Alps and north-western Dinaric Alps. Period. Biol. 112 (3), 239-246.

Chabal, L., 1992. La représentativité paléo-écoloqique des charbons de bois archéologiques issus du bois de feu (The paleoecological representation of archaeological wood charcoal from firewood). Bull. Soc. Bot. Fr. 139, 213-236.

Chabal, L., 1997. Foréts et Sociétés en Languedoc (Néolithique Final, Antiquité Tardive). L' Anthracologie, Méthode et Paléoécologie (Forests and Society in Languedoc (Final Neolithic, Late Antiquity). Anthracology, Method and Paleoecology). Documents d'Archeologie Francaise 63. Éditions de la Maison des Sciences de l' Homme, Paris.

Chabal, L., Fabre, L., Terral, J.F., Théry-Parisot, I., 1999. L'anthracologie (Anthracology). In: Bourquin-Mignot, C., Brochier, J.E., Chabal, L., Crozat, S., Fabre, L., Guibal, F., Marinval, P., Richard, H., Terral, J.F., Théry, I. (Eds.), La Botanique, Paris, France, pp. 43-104.

Čižmař, Z., Kalábková, P., Kazdová, E., Kovárník, J., 2008. The people with Moravian Painted Pottery of the Lengyel culture. In: Čižmař, Zd. (Ed.), Život a smrt v mladšî dobé kamennéLeben und Tod in der Jungsteinzeit. (Life and death in the New Stone Age). Katalog výstavy, Ústav Archeologické Památkové Péče, Znojmopp. 76-87.

Drescher-Schneider, R., 2004. Changes in vegetation and climate in Eastern Austria from the Mesolithic to the Bronze Age: reasons for the migration of Neolithic population. Antaeus 27, 153-163.

Figueiral, I., Mosbrugger, V., 2000. A review of charcoal analysis as a tool for assessing Quaternary and Tertiary environments: achivements and limits. Palaeogeogr Palaeoclimatol. Palaeoecol. 164, 397-407.

Gardner, A.R., 1998. Biotic response to Early Holocene human activity: results from palaeoenvironmental analyses of sediments from Podpesko Jezero. Doc. Prehist. 24 63-77.

Gardner, A.R., 1999. The ecology of Neolithic environmental impacts - re-evaluation of existing theory using case studies from Hungary. Doc. Prehist. 26, 163-183.

Gardner, A.R., Willis, K.J., 1999. Prehistoric farming and the postglacial expansion of beech and hornbeam: a comment on Küster. The Holocene 9, 119-122.

Greguss, P., 1945. A középeurópai lomblevelủ fák és cserjék meghatározása szövettani alapon (Xylotomy of Central European trees and shrubs). Országos Magyar Természettudományi Múzeum, Budapest.

Greguss, P., 1972. Xylotomy of the living conifers. Akadémia Kiadó, Budapest

Gyulai, F., 2001. Archaeobotanika. A kultúrnövények története a Kárpát-medencében a régészeti növénytani vizsgálatok alapján (Archaeobotany: The History of Cultivated Plants in the Carpathian Basin on the Basis of Archaeological Botanical Studies). Jószöveg Mühely, Budapest.
Jacomet, S., Kreuz, A., 1999. Archäobotanik. Aufgaben, Methoden und Ergebnisse vegetations und agrargeschichtlicher Forschung (Archaeobotany. Tasks, Methods and Results of Vegetation and Agro-historical Research). Ulmer, Stuttgart.

Jakab, G., Sümegi, P., Magyari, E., 2004. A new paleobotanical method for the description of Late Quaternary organic sediments (Mire-development pathways and palaeoclimatic records from S Hungary). Acta Geol. Hung. 47, 373-409.

Jakab, G., Majkut, P., Juhász, I., Gulyás, S., Sümegi, P., Törőcsik, T., 2009. Palaeoclimatic signals and anthropogenic disturbance from the peatbog at Nagybárkány (North Hungary). Palaeohydraulics 631, 87-106.

Jansen, D., Nelle, O., 2012. The Neolithic woodland - archaeoanthracology of six Funnel Beaker sites in the lowlands of Germany. J. Archaeol. Sci. http://dx.doi.org/10.1016/ j.jas.2012.10.024

Juhász, I., 2002. The Palynographic Reconstruction of the Late Glacial and the Holocene Periods of County Zala, South West Hungary (Reconstruction palynographique de Tardiglaciaire et de l'Holocene de la région de Zala, Sudouest de la Hongrie). (PhD dissertation) Universities of Marseilles-Pécs.

Juhász, I., 2004. Palynological evidence of Preneolithization in South-Western Transdanubia. Antaeus 27, 213-225.

Juhász, I., 2005. Preliminary palynological results from the Nádas-Tó peat bog at Nagybárkány, north-east Hungary. The late holocene environmental history. In: Gál, E., Juhász, I., Sümegi, P. (Eds.), Environmental Archaeology in North-Eastern HungaryVar. Arch. Hun 19. Archaeological Institute, Budapest, pp. 79-85.

Juhász, I., 2007. Comparison and correlation of four pollen sequences from the Little Balaton region (Alsópáhok, Fönyed, Keszthely and Zalavár). In: Zatykó, Cs., Juhász, I., Sümegi, P. (Eds.), Environmental Archaeology in Transdanubia. Archaeological Institute of the Hungarian Academy of Sciences, Budapest, pp. 35-51.

Kalicz, N., 1988. Beiträge zur Entstehungsfrage der Lengyel-Kultur (Contributions to the emergence of the Lengyel Culture). Slov. Archeol. 36, 105-118.

Kalicz, N., 1990. Frühneolithische Siedlungsfunde aus Südwestungarn (Early Neolithic settlement finds from South Hungary). Inventaria Praehistorica Hungariae IV. Magyar Nemzeti Múzeum, Budapest.

Kalicz, N., 2001. Der Neuere Forschungstand über der Lengyel Kultur (The recent state of research on the Lengyel culture). In: Regenye, J. (Ed.), Sites and Stones: Lengyel Culture in Western Hungary and Beyond. A review of the current research, pp. 1-7.

Kalicz, N., 2007. The beginning of the prehistoric figurine making in western Transdanubia, Hungary (6000-3000 BC). In: Ilon, G. (Ed.), Wonderful beauties. Human representations in prehistoric Western Hungary, pp. 30-45 (Szombathely).

Kalicz, N., Kreiter, E., Tokai, Z.M., 2007. Die Rolle der Sopot-Kultur in der Entstehung der Lengyel-Kultur auf Grund der Neuen Ausgrabungen in Südwestungarn (The role of the Sopot culture in the emergence of the Lengyel culture due to the new excavations in South West Hungary). In: Kozłowski, J., Raczky, P. (Eds.), The Lengyel, Polgár and Related Cultures in the Middle/Late Neolithic in Central Europe. Polska Akademia Umiejętności, Kraków, pp. 29-47.

Kalicz, N., Kreiter, A., Kreiter, E., Tokai, Z.M., Tóth, M., Bajnóczi, B., 2012. A neolitikum történeti és krononlógiai kérdései Becsehely-Bükkalja dűlő lelőhelyen (The Neolithic historical and chronological questions in Becsehely-Bükkalja site). In: Kolozsi, B. (Ed.), MUMOSZ IV, Debrecen, pp. 87-170.

Kreuz, A., 1992. Charcoal from ten early Neolithic settlements in Central Europe and its interpretation in terms of woodland management and wildwood resources. Bull. Soc. Bot. Fr. Actual. Bot. 139 (2/3/4), 383-394.

Lang, G., 1994. Quartäre Vegetationsgeschichte Europas. Methoden und Ergebnisse (Quaternary Vegetation History of Europe. Methods and Results). Gustav Fischer Verlag, Jena.

Magri, D., 2008. Patterns of post-glacial spread and the extent of glacial refugia of European beech (Fagus sylvatica). J. Biogeogr. 35 (3), 450-463.

Magri, D., Vendramin, G.G., Comps, B., Dupanloup, I., Geburek, T., Gomory, D., Latalowa, M., Litt, T., Paule, L., Roure, J.M., Tantau, I., Van Der Knaap, W.O., Petit, R.J., De Beaulieu, J.L., 2006. A new scenario for the Quaternary history of European 1146 beech populations: palaeobotanical evidence and genetic consequences. New Phytol. 171, 199-221.

Magyari, E., 2001. A bükk (Fagus sylvatica) és a gyertyán (Carpinus betulus) terjedésének problematikája a Kárpát-medence holocén vegetációfejlődésében (Problems in the Spread of Beech (Fagus sylvatica) and Hornbeam (Carpinus betulus) in the Holocene Vegetation Development of the Carpathian Basin). 4 Magyar Őslénytani Vándorgyülés Kiadványa, Tihany, pp. 26-27.

Magyari, E., Sümegi, P., Braun, M., Jakab, G., 2002. Retarded hydrosere: anthropogenic and climatic signals in a Holocene raised bog profile from the NE Carpathian Basin. J. Ecol. 89, 1019-1032.

Marosi, S., Somogyi, S., 1990. Magyarország kistájainak katasztere I (Microregions in Hungary I). MTA Földrajztudományi Kutató Intézet, Budapest.

Neumann, K., 1992. The contribution of anthracology to the study of the late Quaternary vegetation history of the Mediterranean region and Africa. Bull. Soc. Bot. Fr. Actual. Bot. 139 (2/4), 421-440.

Oross, K., Bánffy, E., 2009. Three successive waves of Neolithisation - LBK development in Transdanubia. Doc. Praehist. 36, 175-189.

Oross, K., Marton, T., Whittle, A., Hedges, E.R.M., Cramp, L.J.E., 2010. Die Siedlung der Balaton-Lasinja-Kultur in Balatonszárszó-Kis-erdei-dűlö (The settlement of the Balaton Lasinja culture in Balatonszárszó-Kis-erdei-dủlő). In: Suteková, J., Pavúk, P., Kalábková, P. Kovár, B. (Eds.), Panta Rhei. Studies in chronology and cultural development of South-Eastern and Central Europe in earlier prehistory presented to Juraj Pavúk on the occasion of his 75. birthday. Comenius University in Bratislava, Bratislava, pp. 161-187.

Payette, S., 1992. Fire as a controlling process in the North American boreal forest. In: Shugart, H.H., Leemans, R., Bonan, G.B. (Eds.), A systems analysis of the global boreal forest. Cambridge University Press, Cambridge, pp. 144-169.

P. Barna, J., 1996. A lengyeli kultúra tömegsírja Esztergályhorvátiban (The common grave of the Lengyel Culture in Esztergályhorváti, County Zala). Zalai Múz. 6, 149-160. 
P. Barna, J., 2004. Becsehely-Homokos. Előzetes a M7 gyorsforgalmi út 71. sz. lelőhelyén feltárt neolitikus telep kutatásáról (1999. augusztus-2000. március). Report from the 71st Neolithic site of Motorway M7. MUMOSZ II, pp. 33-44.

P. Barna, J., 2007a. Sormás-Török-földek: a new site of the Lengyel Culture in southern Transdanubia. In: Kozlowski, J., Raczky, P. (Eds.), The Lengyel, Polgar and related cultures in the Middle/Late Neolithic in Central Europe. Polish Akademy, Krakow, pp. 365-380.

P. Barna, J., 2007b. Középső és késői újkőkor átmenete: Sopot kultúra. Sormás-Mántaidủlö és Sormás-Török-földek (Transition of the Middle and Lste Neolithic: Sopot culture. Sormás-Mántai-dủlő and Sormás-Török-földek). In: Ilon, G. (Ed.), Wonderful beauties. Human representations in prehistoric Western Hungary, pp. 84-99 (Szombathely).

P. Barna, J., 2009. Újabb adatok a dunántúli Sopot-kultúra kultuszéletéhez. Késő neolitikus absztrakt állat alakú oltárok a DNy-Dunántúlról (The cult life of the Transdanubian Sopot culture. Abstract animal altars of the Late Neolithic from south-western Transdanubia). In: †Bende, L., Lőrinczy, G. (Eds.), Medinától Etéig. Régészeti tanulmányok Csalog József születésének 100. évfordulójára, pp. 215-224 (Szentes).

P. Barna, J., 2010. Sormás-Török-földek. Településtörténeti áttekintés II. A késő neolitikum (The history of a settlement at Sormás-Török-földek II. Late Neolithic). Zalai Múz. 19, 93-115.

P. Barna, J., 2014. Socio-historical background of cultural changes in South-WesternHungary as reflected by archaeological data during Post-LBK times. Anthropologie. EAA Conference, Pilsen (in press).

P. Barna, J., Biró, T.K., 2009. Import leletek és nyersanyagok Sormás-Mántai-dűlő és Sormás-Török-földek lelöhelyeken (Import finds and raw materials from SormásMántai-dűlő and Sormás-Török-földek). In: Ilon, G. (Ed.), Őskoros Kutatók VI. Összejövetelének konferenciaköteteProceedings of the 6th Meeting for the Researchers of Prehistory. MUMOSZ VI, Szombathely, pp. 279-294.

P. Barna, J., Pásztor, E., 2011. Different ways of using space: traces of domestic and ritual activities in a Late Neolithic settlement in a site at Sormás-Török-földek. Doc. Praehist. 38, 185-206.

Rudner, E.Z., 1994. Felső pleisztocén vegetáció rekonstrukciója Magyarországon faszénelemzések alapján (Upper Pleistocene vegetation reconstruction based on charcoal analysis in Hungray). Diploma work University of Debrecen, Debrecen (in Hungarian).

Rudner, E.Z., 2001. Felső pleisztocén vegetációtörténeti és paleoökológiai rekonstrukció a Magyarországon faszénvizsgálatok alapján (Upper Pleistocene vegetation history and paleoecological reconstruction on the basis of charcoal studies in Hungary). (PhD Dissertation) University of Pécs, Pécs.

Rudner, E.Z., 2002. Charcoal as a remain of natural and human-set fires of Palaeolithic Times - case study from Hungary. Br. Archaeol. Rep. 1089, 11-18.

Rudner, E., Sümegi, P., Bajzáth, J., Torma, A., Jakab, G., 2004. The results of wood anatomy, charcoal and fruit and seed analyses. In: Sümegi, P., Gulyás, S. (Eds.), The geohistory of Bátorliget Marshland. Archaeolingua Press, Budapest, pp. 173-182.

Schweingruber, F.H., 1990. Mikroskopische Holzanatomie (Microscopic wood anatomy). Eidgenössiche Forschungsantalt für Wald, Schnee und Landchaft, Birmensdorf.

Shackleton, C.M., Prins, F., 1992. Charcoal analysis and the "Principle of Least Effort" - a conceptual model. J. Archaeol. Sci. 19, 631-637.

Stadler, P., Ruttkay, E., 2007. Absolute chronology of the Moravian-Eastern-Austrian group (MOG of the Painted Pottery (Lengyel Culture) based on the new radiocarbon dates from Austria). In: Kozłowski, J., Raczky, P. (Eds.), The Lengyel, Polgár and Related Cultures in the Middle/Late Neolithic in Central Europe. Polska Akademia Umiejętności, Kraków, pp. 117-146.

Stewart, J.R., Lister, A.M., 2001. Cryptic northern refugia and the origins of the modern biota. Trends Ecol. Evol. 16, 608-613.

Stieber, J., 1964. Die Anthrakotomische Untersuchung der Holzkohlen (Anthracological investigation of charcoal). In: Vértes, L. (Ed.), Tata, eine mittelpaläolitische TravertinSiedlung in Ungarn. Archaeologica Hungarica Series 43, pp. 79-83.

Stieber, J., 1967. A Magyarországi Felsőpleisztocén vegetáció története az anthrakotómiai eredmények tükrében (The Hungarian Upper Pleistocene vegetation history in the light of anthracological results). Föld. Közl. 97, 308-317.

Sümegi, P., 1989. Hajdúság felső-pleisztocén fejlődéstörténete finomrétegtani (üledékföldtani, őslénytani, geokémiai) vizsgálatok alapján (Late Pleistocene evolution of Hajdúság based on stratigraphic (sedimentological, paleontological, geochemical) studies). (PhD Dissertation) University of Debrecen, Debrecen.

Sümegi, P., 1997. Az ÉK-magyarországi löszterületek összehasonlító őskörnyezeti és sztratigráfiai értékelése (The comparative palaeoenvironmental and stratigraphic analysis of NE Hungarian loess areas). (Candidate Dissertation)Poligrafia Inspektoratu Towarzystwa Salezjańskiego, Debrecen.

Sümegi, P., 1998. Az utolsó 15000 év környezeti változásai és hatásuk az emberi kultúrákra Magyarországon (Environmental changes and their impact on human cultures in Hungary for the last 15.000 years). In: Ilon, G. (Ed.), A régésztechnikusok kézikönyve. Savaria Kiadó, Szombathely.
Sümegi, P., 2001. A negyedidőszak földtani és őskörnyezettani alapjai (Geologic and palaeoenvironmental basics of Quaternary). JATEPress, Szeged.

Sümegi, P., 2003. A régészeti geológia és a történeti ökológia alapjai (Basics of geoarchaeology and historical ecology). JATEPress, Szeged.

Sümegi, P., 2004a. The results of paleoenvironmental reconstruction and comparative geoarchaeological analysis for the examined area. In: Sümegi, P., Gulyás, S. (Eds.) The Geohistory of Bátorliget Marshland. Archaeolingua Press, Budapest, pp. 301-348

Sümegi, P. 2004b. Preneolitizáció - egy Kárpát-medencei, késő-mezolitikum során bekövetkezett életmódbeli változás környezettörténeti rekonstrukciója (Preneolithization - environmental historical reconstruction of a lifestyle change in the Carpathian Basin, during the Late Mesolithic). MUMOSZ II, Debrecen, pp. 21-32.

Sümegi, P., 2005. Loess and Upper Paleolithic Environment in Hungary. An Introduction to the Environmental History of Hungary. AUREA Kiadó, Nagykovácsi.

Sümegi, P., 2007a. Palaeogeographical background of the Mesolithic and Early Neolithic settlement in the Carpathian Basin. In: Kozlowski, J.K., Nowak, M. (Eds.), Mesolithic Neolithic Interactions in the Balkans and in the Middle Danube BasinBAR International Series 1726. Archeopress, Oxford, pp. 45-53.

Sümegi, P., 2007b. Zárójelentés a Zala Megyei Múzeumok Igazgatóság részére a Szegedi Tudományegyetem Földtani és Őslénytani Tanszékén végzett környezettörténeti munkáról (Final Report to the Board of Directors of Zala County Museum about the Environment Historical Work of Department of Geology and Palaeontology, University of Szeged). Report.

Sümegi, P., 2013. Pre-Neolithization: reconstructing the environmental background to life way changes in the Late Mesolithic of the Carpathian Basin. In: Baldia, M.O., Perttula T.K., Frink, D.S. (Eds.), Comparative Archaeology and Paleoclimatology. Socio-cultura Responses to a Changing WorldBAR International Series 2456. Archeopress, Oxford, pp. 109-117.

Sümegi, P., Kertész, R., Rudner, E.Z., 2004. Paleoenvironmental history of Hungary. In: Visy, Zs. (Ed.), Hungarian Archeology at the Turn of the Millenium. Nemzeti Kulturális Örökség Minisztériumának Kiadványa, Budapest, pp. 51-56.

Sümegi, P., Ilon, G., Jakab, G., Páll, D.G., Törőcsik, T., 2009. Neolit és rézkori régészet kultúrák és környezeti hátterük az Alpokaljáról (Neolithic and Copper Age archaeological cultures and environmental background from West Hungary). In: Bende, L. Lörinczy, G. (Eds.), Medinától Étig. Régészeti tanulmányok Csalog József születésének 100. évfordulójára. Koszta József Múzeum Kiadványa, Szentes, pp. 189-195.

Sümegi, P., Náfrádi, K., Töröcsik, T., 2011a. The methodology employed. In: Kvassay, J. (Ed.), The Late Urnfield Period Cemetery From Szombathely-Zanat Supplemented by an Assessment Features and Interdisciplinary AnalysesVIA-Monographia Minor Cultural Heritage 2. Hungarian National Museum, Natural Cultural Heritage Protection Centre, Budapest, pp. 203-214

Sümegi, P., Persaits, G., Páll, D.G., Töröcsik, T., 2011b. Results of analysis carried out in the alluvium of Borzó Creek and at the Zanat archaeological site. In: Kvassay, J. (Ed.), The Late Urnfield Period Cemetery From Szombathely-Zanat Supplemented by an Assessment Features and Interdisciplinary AnalysesVIA-Monographia Minor Cultural Heritage 2. Hungarian National Museum, Natural Cultural Heritage Protection Centre, Budapest, pp. 224-243.

Sümegi, P., Rudner, E., 2001. In situ charcoal fragments as remains of natural wild fires of the Upper Würm in the Carpathian Basin. Quat. Int. 76/77, 165-176.

Törőcsik, T., 2005. A Duna-völgyi láposodott területek (Ócsa, Kecel, Császártöltés, Hajós) pollenelemzésének eredményei (Results of pollen analysis of flattened areas of Danube (Ócsa, Kecel, Császártöltés, Hajós)). Jelentés az NKTH Magyarország környezettörténete pályázathoz, SZTE Földtani és Öslénytani Tanszék, Report.

Törőcsik, T., 2006. A dunántúli pollenszelvények (Mezőlak, Sárrét, Balatonederics, Velem, Osli, Hidegség) revíziójnak eredményei (Pollen profiles of Transdanubia (Mezőlak, Sárrét, BValatonederics, Velem, Osli, Hidegség). Jelentés az NKTH Magyarország környezettörténete pályázathoz, SZTE Földtani és Öslénytani Tanszék, Report.

Vernet, J.-L., 2002. Preface. Proceedings of the 2nd International Meeting of Anthracology. In: Thiébault, S. (Ed.), Charcoal Analysis. Methodological Approaches, Palaeoecological Results and Wood UsesBAR International Series 1063. Archaeopress, Oxford.

Western, C.A., 1971. The ecological interpretation of ancient charcoals from Jericho. Levant 3, 31-40.

Willcox, G., 2002. Evidence for ancient forest cover and deforestation from charcoal analysis of ten archaeological sites on the Euphrates. In: Thiébault, S. (Ed.), Charcoal Analysis: Methodological Approaches, Palaeoecological results and Wood UsesBAR International Series 1063. Archaeopress, Oxford.

Willis, K.J., Braun, M., Sümegi, P., Tóth, A., 1997. Does soil change cause vegetation change or vice-versa? A temporal perspective from Hungary. Ecology 78, 740-750.

Willis, K.J., Sümegi, P., Braun, M., Bennett, K.D., Tóth, A., 1998. Prehistoric land degradation in Hungary: who, how and why? Antiquity 72, 101-113. 